Elsevier

BRE 20103

\title{
Some efferent connections of the superficial pretectum in the goldfish
}

\author{
R. GLENN NORTHCUTT ${ }^{\mathbf{l}}$ and MARK R. BRAFORD, Jr. ${ }^{2}$ : \\ Division of Biological Sciences, University of Michigan, Ann Arbor, MI 48109, and Department of Anatomy, \\ Georgetown University, Washington, DC 20007 (U.S.A.)
}

(Accepted November 22nd, 1983)

Key words: pretectum - diencephalon - teleost - degeneration - horseradish peroxidase - connections

\begin{abstract}
The diencephalic nuclei known as the lateral geniculate and rotundus in goldfish appear to belong to the pretectal region. They do not project to the telencephalon. A combination of degeneration and horseradish tract-tracing experiments show that the latter nucleus projects caudally to the so-called mammillary body and to a precerebellar cell group-nucleus lateralis valvulae.
\end{abstract}

The lateral geniculate nucleus and nucleus rotundus* are two prominent cell groups (Fig. 1A) in the diencephalon of the goldfish ${ }^{20}$. These two nuclei have also been recognized in many other teleosts, as well as in other ray-finned fishes. The names given to these nuclei appear to have been based on the assumption that they lie in the thalamus and have carried with them at least the connotations of homologies with similarly named nuclei in other vertebrates. As such, one or both of these cell groups might well be expected to project to the telencephalon. However, based on a comprehensive cytoarchitectonic and topographic analysis of the diencephalon and pretectum of several ray-finned fishes including the goldfish, Carassius auratus, these two nuclei have recently been assigned to the pretectum and renamed nucleus pretectalis superficialis, pars parvocellularis (PSp) and pars magnocellularis (PSm), respectively $2,3,18$.

In order to determine whether any part of the superficial pretectal nucleus projects to the telencephalon, 4 specimens of Carassius auratus (total length: ca. $15 \mathrm{~cm}$ ) were anesthesized with tricaine methansulfonate and the pretectum was exposed by removal of one eye and the underlying neurocranial wall. The position of the superficial pretectal nucleus was ap- parent as a small, surface mound lying between the arms of the dorsal and ventral optic tracts and was easily disrupted by aspiration with a small cannula. The animals were allowed to survive 8-13 days postoperatively at $21-25^{\circ} \mathrm{C}$ and were then re-anesthetized and perfused with $0.7 \%$ saline followed by $10 \%$ formalin. The brains were subsequently processed and stained for degenerating axons and terminals using several modifications of the Fink-Heimer technique 5 .

No degenerating fibers or terminals were traced to or seen in the telencephalon. Degenerating retinofugal fibers and their terminals that resulted from the removal of one eye were seen largely on the side contralateral to the lesion. Ipsilaterally, a compact bundle of degenerating fibers was traced caudoventrally from the aspiration lesion in the pretectum (Fig. 2). This bundle corresponds, at least in part, to the tractus thalamo-mammillaris of Goldstein ${ }^{7}$ and others and the tractus rotundus of Schnitzlein ${ }^{20}$. Near the caudal border of the diencephalon this tract passes through a field of large neurons (the nucleus lateralis thalami of Holmgren ${ }^{11}$ and Bergquist ${ }^{1}$ or the nucleus ruber of Goldstein ${ }^{7}$ and Sheldon ${ }^{22}$ ) and may terminates sparsely on them. A large component of this bundle courses ventromedially and terminates ex-

Correspondence: R. G. Northcutt, Division of Biological Sciences, University of Michigan, Ann Arbor, MI 48109, U.S.A.

* This nucleus has also been called nucleus anterior thalami6,7,11,22. It is not to be confused with either the nucleus rotundus of Sheldon ${ }^{22}$ or the glomerular nucleus of the caudobasal diencephalon which has sometimes also been called nucleus rotundus. 

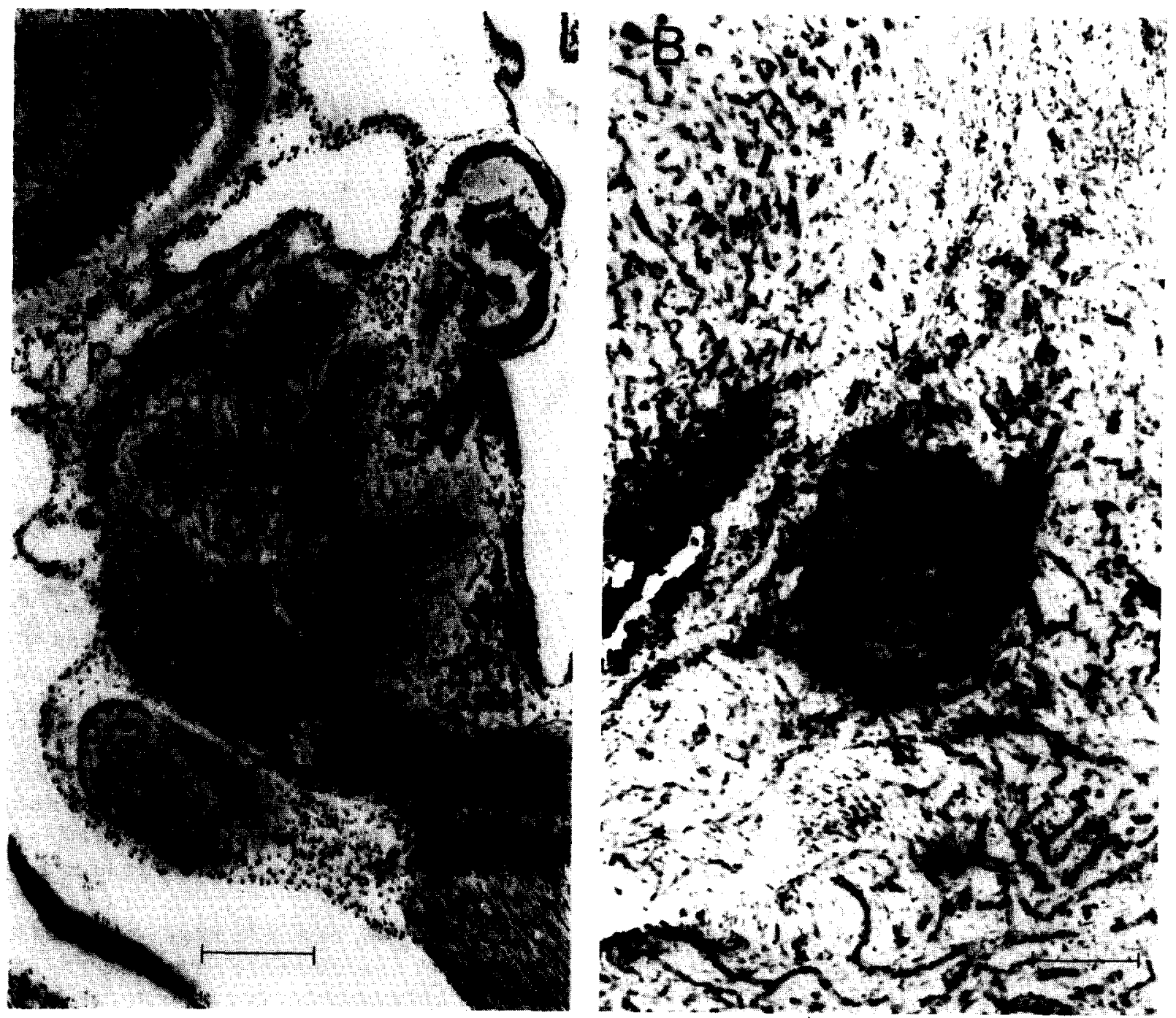

Fig. 1. A: photomicrograph of a transverse section stained by the Bodian method through one side of the diencephalon showing the relative positions of the pars parvocellularis $(\mathrm{p})$ and the neuropil $(\mathrm{n})$ and cell plate $(\mathrm{m})$ of the pars magnocellularis of the superficial pretectal nucleus. B: photomicrograph of a transverse section through the pars magnocellularis demonstrating retrogradely labeled cells bodies and neuropil following an HRP injection into the ipsilateral corpus mammillare. Bar scales indicate 200 and $100 \mu \mathrm{m}$ in $\mathrm{A}$ and $B$, respectively.

tremely densely in a cell group which lies on the dorsomedial aspect of the inferior lobe of the hypothalamus. This cell group has traditionally been called the corpus mammillare or mammillary body. A smaller dorsal component of the main tract continues caudally for a short distance before sweeping dorsally to terminate in rostromedial portions of the nucleus lateralis valvulae

In an attempt to determine which portion of the superficial pretectal nucleus gives rise to the major ventral component of this pathway, 40-60 $\mathrm{nl}$ of HRP (Sigma Type VI, $40 \%$ ) was pressure injected unilaterally into the 'mammillary body' in two additional animals. Following survival times of four days at $23{ }^{\circ} \mathrm{C}$, the animals were sacrificed and the tissue was processed according to the methods of Mesulam ${ }^{13}$ and Hanker et al. ${ }^{10}$. In one of the two cases the injection was centered in and restricted to the mammillary body. HRP-labeled fibers were seen in both the ventral and dorsal components of the pathway and nearly all of the large cells which form the rim of PSm were retrogradely filled with HRP (Fig. 1B). No HRP-labeled fibers, terminals or cell bodies were seen in PSp. We interpret these results to mean that the axons of these 
A
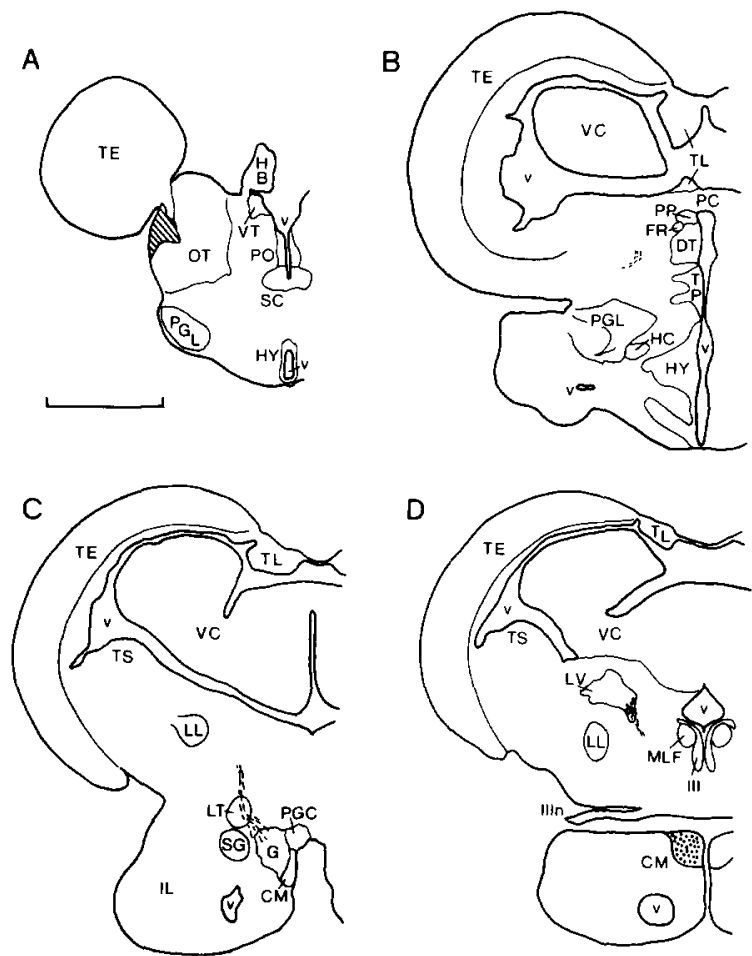

Fig. 2. Drawings of transverse sections through one side of the diencephalon and mesencephalon on which have been plotted degenerating fibers and terminals seen following an aspiration lesion of the superficial pretectum. The extent of the lesion is shown by hatching in section $\mathrm{A}$, which is the most rostral section. Degenerating fibers are indicated by dashed lines and degenerating terminals by dots. Bar scale; $1 \mathrm{~mm}$.

large neurons of PSm form a major part of tractus rotundus, that they project to the mammillary body, and that at least some of them send collaterals to nucleus lateralis valvulae.

\section{LIST OF ABBREVIATIONS}

$\begin{array}{ll}\text { CM } & \text { corpus mammillare } \\ \text { DT } & \text { dorsal thalamus } \\ \text { FR } & \text { fasciculus retroflexus } \\ \text { G } & \text { nucleus glomerulosus of Schnitzlein } \\ \text { HB } & \text { habenula } \\ \text { HC } & \text { horizontal commissure } \\ \text { HY } & \text { hypothalamus } \\ \text { IL } & \text { inferior lobe of hypothalamus } \\ \text { LL } & \text { lateral lemniscus } \\ \text { LT } & \text { nucleus lateralis thalami of Holmgren and Bergquist } \\ \text { LV } & \text { nucleus lateralis valvulae } \\ \text { MLF } & \text { medial longitudinal fasciculus } \\ \text { OT } & \text { optic tract } \\ \text { PC } & \text { posterior commissure }\end{array}$

PSm is known to receive a bilateral input from the optic tectum in Carassius ${ }^{8,9}$ and in this respect resembles the nucleus rotundus of reptiles and birds. However, neither its topographical position nor its efferent connections, demonstrated here, support such a homology.

$\mathrm{PSp}$ is known to receive a direct retinal input in Carassius $^{3,21,24}$, but its topographical position and the fact that it does not appear to project to the telencephalon make it a poor candidate for a homologue of the dorsal portion of the lateral geniculate nucleus of land vertebrates. Previous studies using various methods have suggested different targets for PSp. Holmgren 11 using the Golgi method, suggested that PSp projects to the optic tectum in Osmerus, but tectal HRP injections in Cyprinus ${ }^{12}$ and Lepomis ${ }^{17}$ have failed to label cells of PSp. This is consistent with the results of the present study. Retrograde labeling of PSp cells following HRP injections into the eye in $J u$ lidochromis and Tetraodon has been reported ${ }^{4}, 15$. A number of other studies using HRP or cobaltous-lysine have, however, failed to demonstrate this connection in other teleosts, including Carassius ${ }^{14,16,}$ 19,23-25. Further studies are needed to establish the efferent connections of PSp and can probably best be carried out in a species in which PSp is both larger and less closely associated with PSm than it is in Carassius, as is the case in many perciform teleosts.

This work was supported by NIH Grant EY02485 to R.G.N. and NSF Grant BNS 8118844 to M.R.B.
PGC nucleus preglomerulosus commissuralis

PGL preglomerular nuclear complex

PO posterior parvocellular preoptic nucleus

$\mathrm{PP} \quad$ periventricular pretectal nucleus

SC suprachiasmatic nucleus

SG nucleus subglomerulosus

TE optic tectum

TL torus longitudinalis

TP posterior tuberculum

TS torus semicircularis

$v$ ventricle

VC valvula cerebelli

VT ventral thalamus

III oculomotor nucleus

IIIn oculomotor nerve 
1 Bergquist, H., Zur Morphologie des Zwischenhirns bei niederen Wirbeltieren, Acta Zool., 13 (1932) 57-304.

2 Braford, M. R., Jr. and Northcutt, R. G., Organization of the thalamus in the longnose gar, Lepisosteus osseus, Soc. Neurosci. Abstr., 4 (1978) 77.

3 Braford, M. R., Jr. and Northcutt, R. G., Organization of the diencephalon and pretectum of the ray-finned fishes. In R. G. Northcutt and R. E. Davis (Eds.), Fish Neurobiology, University of Michigan Press, Ann Arbor, in press.

4 Ebbesson, S. O. E. and Meyer, D. L., Efferents to the retina have multiple sources in teleost fish, Science, 214 (1981) 924-926.

5 Fink, R. P. and Heimer, L., Two methods for selective silver impregnation of degenerating axons and their synaptic endings in the central nervous system, Brain Research, 4 (1967) 369-374

6 Franz, V., Beitrage zur Kenntnis des Mittelhirns und Zwischenhirns der Knochenfische, Folia neuro-biol., 6 (1912) 402-441.

7 Goldstein, K., Untersuchungen ueber das Vorderhirn und Zwischenhirn einiger Knochenfische (nebst einigen Beitragen ueber Mittelhirn und Kleinhirn derselben), Arch. Mikr. Anat., 66 (1905) 135-219.

8 Grover, B. G. and Sharma, S. C., Tectal projections in the goldfish (Carassius auratus): a degeneration study, $J$. comp. Neurol., 184 (1979) 435-454.

9 Grover, B. G. and Sharma, S. C., Organization of extrinsic tectal connections in goldfish (Carassius auratus), J. comp. Neurol., 196 (1981) 471-488.

10 Hanker, J. S., Yates, P. E., Metz, C. B. and Rustioni, A., A new specific, sensitive and non-carcinogenic reagent for the demonstration of horseradish peroxidase, Histochem. J., 9 (1977) 789-792.

11 Holmgren. N., Zur Anatomie und Histologie des Vorderund Zwischenhirns der Knochenfische, Acta Zool., 1 (1920) 137-315

12 Luiten, P. G. M., Afferent and efferent connections of the optic tectum in the carp (Cyprinus carpio L.), Brain Research, 220 (1981) 51-65.
13 Mesulam, M.-M., Tetramethyl benzidine for horseradish peroxidase neurohistochemistry: a non-carcinogenic blue reaction product with superior sensitivity for visualizing neural afferents and efferents, J. Histochem. Cytochem., 26 (1978) 106-117.

14 Meyer, D. L. and Ebbesson, S. O. E., Retinofugal and retinopetal connections in the upside-down catfish (Synodontis nigriventris), Cell Tissue Res., 218 (1981) 389-401.

15 Meyer, D. L., Fiebig, E. and Ebbesson, S. O. E., A note on the reciprocal connections between the retina and the brain in the puffer fish Tetraodon fluviatilis, Neurosci. Lett., 23 (1981) 111-115.

16 Munz, H. and Claas, B., Centrifugal innervation of the retina in cichlid and poecilid fishes. A horseradish peroxidase study, Neurosci. Lett., 22 (1981) 223-226.

17 Northcutt, R. G., Cells of origin of pathways afferent to the optic tectum in the green sunfish, Lepomis cyanellus, Invest. Vis. Sci., 22 (1982) 245.

18 Northcutt, R. G. and Butler, A. B., Projections of the optic tectum in the longnose gar, Lepisosteus osseus, Brain Research, 190 (1980) 333-346.

19 Schmidt, J. T., The laminar organization of optic nerve fibers in the tectum of goldfish, Proc. roy. Soc. B, 205 (1979) 287-306.

20 Schnitzlein, H. N., The habenula and dorsal thalamus of some teleosts, J. comp. Neurol., 118 (1962) 225-267.

21 Sharma, S. C., The retinal projections in the goldfish: an experimental study, Brain Research, 39 (1972) 213-224.

22 Sheldon, R. E., The olfactory tracts and centers in teleosts, J. comp. Neurol., 22 (1912) 177-339.

23 Springer, A. D., Centrifugal innervation of goldfish retina from ganglion cells of the nervus terminalis, J. comp. Neurol., 214 (1983) 404-415.

24 Springer, A. D. and Gaffney, J. S., Retinal projections in the goldfish: a study using cobaltous-lysine, J. comp. Neurol., 203 (1981) 401-424.

25 Uchiyama, H., Sakamoto, N. and Ito, H., A retinopetal nucleus in the preoptic area in a teleost, Navodon modestus, Brain Research, 222 (1981) 119-124. 